\title{
Professional Skills Acquisition and Human Capital Development: Implications for Higher Education Institutions
}

\author{
Clara N. Olele ${ }^{1}$, Chineze M. Uche ${ }^{2, *}$ \\ ${ }^{1}$ Department of Curriculum Studies and Educational Technology \\ ${ }^{2}$ Department of Educational Management (University of Port Harcourt). [ ${ }^{*}$ Corresponding author. \\ E-mail: nezenwam@yahoo.com]
}

\begin{abstract}
This study delved into University of Port Harcourt (UPH) and Rivers State University of Science and Technology (RSUST) lecturers' approaches to professional development. Lecturers in the faculties of education in the universities constituted the target population from which a random sample of 120 respondents was selected. Data were collected using a questionnaire and analyzed using percentages, means and standard deviations. The findings were that new entrants into the teaching profession were not exposed to comprehensive induction programmes; the strategies used for professional development were limited; and new entrants into teaching were disposed towards mentoring. It was also found that new entrants into the teaching profession would prefer to be mentored in all the domains of knowledge management. Grounded on these findings, the study suggests ways of improving the acquisition of professional skills among lecturers in the universities.
\end{abstract}

Keywords: Career mentoring; Induction; Professional development

\section{$1 \quad$ Introduction}

Training is a learning process of knowledge acquisition, sharpening of attitudes and skills that result from the teaching of practical skills and knowledge which relate to specific useful competencies and rules. There is no doubt that training primarily focuses on helping teachers acquire the knowledge and skills they need to develop as effective performers. Development focuses on building the knowledge and skills and takes the form of learning activities that prepare people to take on new responsibilities and challenges (Jones \& George, 2003; Armstrong, 2009). However, before creating training or development programs 
in a work environment, there should be a thorough needs assessment to determine who needs training or development and what type of skills or knowledge they need to acquire (Lee \& Owens, 2004)

Although both classroom instructions and on-the-job training can be used for development processes as well as training, development often includes additional activities such as varied work experiences and formal education. Varied work experiences such as secondment and short sabbaticals are most powerful sources of career development as they tend to broaden teachers' horizons and help them think more about globalization, with which they will develop understanding of human values, global issues/problems, cultures, and ways of teaching in different countries (Pollard, Anderson, Maddock, Swaffield, Warin \& Warwick, 2008).

Professional development begins with initial teacher training, followed by induction to introduce new entrants to new jobs and institutions (Robbins \& Coulter, 2005). Ornstein \& Levine (2006) refer to this as mediated entry, which is the practice of inducting through carefully supervised stages that help the new entrants learn how to successfully apply professional knowledge in work environments.

Dan-Lortie (1975) cited in Ornstein \& Levina (2006) reports lack of carefully mediated entry into the teaching profession. According to them, teachers report learning to teach through trial and error and experiences in the classroom after the initial training; and as such, do not have smooth outsideinside transition. Bluen \& Nayler (2004) argue that experiences depending solely on trial and error cannot result into competence. Experiences and training are not incompatible as methods of learning; in proper proportion, the two can lead to the highest efficiency and maximum achievement in the shortest time.

Sadker \& Sadker (2003) suggest that the best professional development program in education should connect directly to teachers work in relation with students. To Sadker \& Sadker (2003) and Obanya (2007), collaborative action research connects daily teaching activities with professional growth. This is done as practicing teachers identify real classroom problems, then research on the problems and use the information generated to improve the quality of teaching/learning.

For teachers in higher education institutions, coaching, mentoring, secondment, peer observation and short sabbaticals, are powerful sources of learning on-the-job. These processes of staff development are based on pragmatic advice, guidance, mutual respect, and follow-up discussions. They provide opportunities for individual teachers to pursue personal areas of interest within the context of the work environment (Pollard, Anderson, Maddock, Swaffield, Warin \& Warwick, 2008).

An important conduit for institutional staff development is mentoring and coaching. Mentoring, as defined by Hughes, Ginnett \& Curphy (2006) is a 
personal relationship, in which a more experienced person acts as a guide, role model and sponsor to a protégé. Mentors prepare individuals to perform better in the future and groom them for higher and greater positions. Although mentoring has a strong development component, it is not the same as cognitive apprenticeship or coaching. Dennen \& Burner (2009); Armstrong (2009) and Miller (2002) distinguished between coaching and mentoring. Coaching is a personal on-the-job approach to help people develop their levels of competence. It is more directive while mentoring is a non- directive relationship. Mentoring is also more broadly focused on the protégé.

Concepts derived from two theoretical perspectives inspired this present paper. The first is the Social Constructivist Theory of Vygotsky (1968). The second is the Situated Learning theory of Lave \& Wenger (1991). Vygotsky stressed the importance of culture and social context in learning. His main contribution to our understanding of learning is his concept of the zone of proximal development which refers to the gap between what individuals can do alone and unaided and what can be achieved with the help of more knowledgeable others. Coaching and mentoring fall within this category, as they depend on others that are more knowledgeable.

Building on the foundation provided by Vygotsky, the proponents of Situated Learning argue that to be useful, knowledge must be situated in an authentic task and setting (Lave \& Wenger, 1991). Knowledge, according to Lave \& Wenger (1991) is to a great extent the product of the situation, culture and activity. This implies that the mentoring and coaching environment are situated and constructed.

According to Armstrong (2009), a formal mentoring programme occurs when an institution assigns a relatively inexperienced but highly promising employee to one of the top executives in the establishment. Menttium (2004) posits that in many cases, organization implement formal mentoring programmes to accelerate the development of minorities. Miller (2002) also lists some attributes of good mentors which (coincidentally) are the key components of emotional intelligence. Effective mentoring is more than providing work-related support; emotional bonds between a mentor and a protégé can enable the protégé express fears, concerns, and sometimes even reluctance to follow advice.

Clutterbuck (1998) identifies behaviours that mentors should use and those that they should not use. He recommends that mentors should sometimes use coaching; be role models, and be sponsors, but that they should never discipline, condemn, formally appraise, assess for a third party and supervise the mentee. Lave \& Wenger (1991) studied learning in five traditional and nontraditional apprenticeship settings in Mexico, Liberia and the United States. The study showed how work setting learning occurred with 'communities of practice'. Apprentices moved from peripheral observers in the work place as 
newcomers to the central role over time as they perfected their learning and finally become experts and succeeded the craft people from whom they had learnt.

Billet (2000) studied the learning process of mentees in a formal workplace for over six month period. This prolonged engagement allowed him to identify learning sources and strategies that were influential on the mentees' development. The mentees were trained in a workplace that guided their learning strategies and Billet suggests that the different strategies kept the learners actively engaged.

Young \& Perrewe (2000) look at career and social support factors in relationship to mentoring. They found that mentors' expectations generally were not met when protégés were involved in career support behaviour. Conversely, mentees tended to measure the success of their mentoring relationship in terms of the amount of social support they received. It was hypothesized that the difference in perception was due to the mentors' established status, which may have them focused on successes directly related to the mentoring goal, while novice protégés may not yet be able to predict the impact of particular career related behaviour, but will look for encouragement and friendship as indicators that they are performing as expected.

In sum, Dennen and Burner (2009: 427) posit that "current educational systems, particularly universities have been criticized for separating learning from practice, resulting in an education that does not sufficiently prepare students for job performance". This implies that these systems lack situated learning experiences for authentic practice in real context; which creates gaps that coaching and mentoring can fill. Therefore, this study was undertaken to find out whether new adult entrants into teaching at University level in Port Harcourt metropolis were inducted into their jobs; to identify the strategies teachers at this level use for professional development; to assess the disposition of teachers at this level towards mentoring; and establish the preferred domain of knowledge management through which these teachers wish to be mentored.

\section{$2 \quad$ Methodology}

The study was carried out in Rivers State, Nigeria, a significant stakeholder State in the Niger Delta area of Nigeria. The population of the study comprised of lecturers in the Faculty of Education in two higher education institutions in Port Harcourt metropolis of Rivers state, Nigeria. One of the institutions is owned by the federal government (UPH), while the other is owned by the State government (RSUST). 
In the Faculty of Education of UPH, there are 120 lecturers while there are 60 in RSUST. From UPH 60 respondents were randomly selected from the six departments (10 per department), while the entire 60 lecturers in the three departments and the Institute of Education of RSUST were selected for the study. In all 120 respondents which cut across Assistant Lecturer to Senior Lecturer were involved in the study. They were selected because they formed the bulk of the teaching staff in the Faculties of Education.

A structured questionnaire titled: "Career Entry and Development Profile" (CEDP) developed by the researchers was the instrument used to elicit information from the respondents. The questionnaire was divided into four sections; the first section made up of 10 items measured the extent to which newly qualified lecturers from the rank of Assistant Lecturers to Senior Lecturers were inducted into teaching at the university level; the second section made up of 10 items determined the strategies commonly used by respondents for professional development; the third section made up of 12 items determined respondents' disposition to mentoring as strategy for professional development; and the fourth section made up of four items determined the extent to which respondents preferred to be mentored in the three knowledge management domain.

Respondents rated items using a four-point Likert type rating scale of $1=$ strongly disagree, $2=$ disagree, $3=$ agree, $4=$ strongly agree. A midpoint of 2.50 was established from the four point rating scale. Based on the mid-point decision was taken thus: any mean score $<2.50$ suggests disagreement with the item, and any mean score $\geq 2.50$ suggests agreement with the item. In addition, the questionnaire included 4 yes and no items, where respondents indicated the domain of knowledge management function they may wish to be mentored most. Experts in measurement and evaluation validated the instrument. Reliability indices of $0.70,0.72$, and 0.75 respectively were established for the three sections using Cronbach Alpha. The instruments were personally administered and retrieved. Data were analyzed using descriptive statistics such as mean scores, standard deviation, and percentages.

\section{$3 \quad$ Findings}

\section{1 Induction of New Entrants into Teaching}

New employees could be nervous and anxious about the new job and environment. To put them at ease, basic information about working arrangement, standard of performance and behaviour expected, geographical layout of the institutions, are all to be included in information pack and 
employees handbook. In addition, institution-wide briefing and site tour should be part of the induction programme to give the induction personal touch beyond variety of document. This will provide opportunities for questions and answers session. Introducing new entrants to senior colleagues will make them feel at home and know who to meet if they need help.

Table 1: Induction of New Employees into their Functions

\begin{tabular}{|c|c|c|c|c|c|c|}
\hline \multirow{2}{*}{ Aspect of Induction } & \multicolumn{3}{|c|}{ UPH $(n=60)$} & \multicolumn{3}{|c|}{ RSUST $(n=60)$} \\
\hline & $\overline{\text { Mear }}$ & n Std. & v Remark & $\overline{\text { Mear }}$ & Std. & Remark \\
\hline I was employed with others in a cohor & $\mathrm{t} 3.60$ & 0.47 & Agree & 4.00 & 0.00 & Agree \\
\hline I was anxious about the new job & 2.91 & 0.86 & Agree & 2.58 & 0.96 & Agree \\
\hline We toured university campus & 1.00 & 0.00 & Disagree & 1.00 & 0.00 & Disagree \\
\hline induction package was suitable for us & 1.25 & 0.43 & Disagree & 1.00 & 0.00 & Disagree \\
\hline We got information packs & 2.16 & 0.80 & Disagree & 1.50 & 0.77 & Disagree \\
\hline We got employees handbook & 1.00 & 0.00 & Disagree & 1.00 & 0.00 & Disagree \\
\hline We had institution-wide initial bri & $g 1.00$ & 0.00 & Disagree & 1.00 & 0.00 & Disagree \\
\hline We were taken round the faculty & 1.00 & 0.00 & Disagree & 1.00 & 0.00 & Disagree \\
\hline We had formal induction courses & 2.58 & 1.12 & Agree & 3.33 & 0.47 & Agree \\
\hline We were introduced to colleagues & 1.40 & 0.40 & Disagree & 1.00 & 0.00 & Disagree \\
\hline Overall mean & 1.79 & & Disagree & 1.74 & & Disagree \\
\hline
\end{tabular}

The findings in Table 1, reveal that respondents from UPH and RSUST disagree that they were taken on tour within and outside the universities with mean scores of 1.00 respectively. Also, respondents from both institutions disagreed that induction package was very suitable for them $(\mathrm{UPH}=1.25$; RSUST $=1.00$ ); Respondents disagreed that they were given information packs $(\mathrm{UPH}=2.16$; RSUST $=1.50)$. It was found that respondents disagreed that they were given employee handbooks $(\mathrm{UPH}=1.00$; RSUST $=1.00)$. They equally disagreed that they had institution-wide initial briefing $(\mathrm{UPH}=1.00$; RSUST $=$ 1.00). In the same vein, respondents indicated that they were not taken round the faculties when offices were assigned to them (UPH=1.00; RSUST=1.00). Respondents disagreed that all the senior colleagues in the faculties were introduced to them $(\mathrm{UPH}=1.40$; RSUST $=1.00)$.

The overall mean scores of 1.79 and 1.74 show low level of induction among respondents in the two institutions under study.

\subsection{Strategies Used for Professional Development}

Professional development of teachers takes different forms. Teachers could develop their career by attending courses, sharing ideas with colleagues, evaluating data to identify weaknesses and they would want to overcome such weaknesses; they could work collaboratively with colleagues as partners; take new responsibilities and learn through experiences. Teachers could observe their peers at work, and attend conferences; they could take advantage of 
information and communication technologies (ICTs) by using CD-ROM, webbased courses/training and use instructional packages.

Table 2: Strategies used for Professional Development

\begin{tabular}{|c|c|c|c|c|c|c|}
\hline \multirow{2}{*}{ Strategy } & \multicolumn{3}{|c|}{ UPH $(n=60)$} & \multicolumn{3}{|c|}{ RSUST $(n=60)$} \\
\hline & $\overline{M e a}$ & Std. Dev & Remark & Mear & Std. dev & Remark \\
\hline Attending courses & 1.00 & 0.00 & Disagree & 1.00 & 0.00 & Disagree \\
\hline Sharing ideas with colleagues & 3.25 & 0.40 & Agree & 3.60 & 0.55 & Agree \\
\hline Action Learning & 1.58 & 0.60 & Disagree & 1.00 & 0.00 & Disagree \\
\hline Working in partnersh & 2.91 & 0.80 & Agree & 2.66 & 0.95 & Agree \\
\hline Taking on $n$ & 3.16 & 0.90 & Agree & 2.66 & 0.95 & Agree \\
\hline bservation & 2.25 & 0.80 & Disagree & 1.00 & 0.00 & Disagree \\
\hline nces & 4.00 & 0.00 & Agree & 4.00 & 0.00 & Agree \\
\hline CD-R & 1.00 & 0.00 & Disagree & 2.33 & 1.00 & Disagree \\
\hline Secc & 1.00 & 0.00 & Disagree & 1.00 & 0.00 & Disagree \\
\hline ional pacl & 1.50 & 0.90 & Disagree & 1.00 & 0.00 & Disagree \\
\hline Inter & 3.25 & 0.40 & Agree & 4.00 & 0.00 & Agree \\
\hline Audi & 1.00 & 0.00 & Disagree & 1.00 & 0.00 & Disagree \\
\hline Overall mean & 2.15 & & Disagree & 2.10 & & Disagree \\
\hline
\end{tabular}

The analysis of the responses on Table 2 shows that professional development by attending courses is low among respondents in the two institutions under study (UPH=1.00; RSUST =1.00). It was also found that action learning in the form of evaluation data, identifying weakness and taking action was low (UPH=1.58; RSUST = 1.00). Professional development was low in the use of peer observation in the two institutions $(\mathrm{UPH}=2.25$; RSUST $=1.00)$. It was also low in the use of CD-ROM (UPH= 1.00; RSUST $=2.33$ ); low in secondment to other institutions $(\mathrm{UPH}=1.00$; RSUST $=1.00)$. Professional development was equally low in the use of instructional package (UPH=1.50; RSUST $=1.00)$; low in audio-based training $(\mathrm{UPH}=1.00$; $\mathrm{RSUST}=1.00)$.

The general low mean scores of 2.15 and 2.10 indicate that most of the strategies for professional development were not being used by the lecturers in the universities under study.

\subsection{Teachers' Disposition towards Mentoring}

Some teachers are disposed to mentoring as an effective career development options. In some cases, mentors are assigned to new entrants into teaching, while in others, they choose their mentors. Some teachers believe that mentoring is an effective career development option as it provides guidancel and supports. Some teachers can approach their mentors for other issues, besides academics alone, while others just limit the relationship to academic alone. Others have co-authored papers with their mentors. Some mentors 
sometimes resort to coaching in an effort to help the protégé. Many protégé later become mentors too.

Table 3: Lecturers' Disposition towards Mentoring for Professional Development

\begin{tabular}{|c|c|c|c|c|}
\hline \multirow{2}{*}{$\begin{array}{l}\text { Aspects of Disposition towards Mentoring } \\
\text { for Career Development }\end{array}$} & \multicolumn{2}{|c|}{ UPH $(n=60)$} & \multicolumn{2}{|c|}{ RSUST $(n=60)$} \\
\hline & $\overline{M e a n}$ & SD Remark & Mear & Remark \\
\hline $\begin{array}{l}\text { We were assigned to mentors upon being } \\
\text { employed }\end{array}$ & 1.00 & 0.00 Disagree & 1.00 & 0.00 Disagree \\
\hline have a mentor of my choice & 3.30 & 0.47 Agree & 3.08 & 0.49 Agree \\
\hline oachable & 3.08 & 0. & 3.00 & 0 \\
\hline $\begin{array}{l}\text { I believe in mentoring as a strategy for } \\
\text { career development }\end{array}$ & 3.25 & 0.43 Agree & 4.00 & 0.00 Agree \\
\hline Mentors provide useful guidance and support & 3.30 & 0.47 Agree & 3.16 & 0.37 Agree \\
\hline $\begin{array}{l}\text { I can approach my mentor for non-academic } \\
\text { matters }\end{array}$ & 3.30 & 0.47 Agree & 2.75 & 0.9 \\
\hline $\begin{array}{l}\text { I have co-authored with my mentor } \\
\text { Sometimes my mentor coaches me }\end{array}$ & $\begin{array}{l}2.60 \\
3.30\end{array}$ & $\begin{array}{l}0.95 \mathrm{Ag} \\
0.47 \mathrm{Ag}\end{array}$ & $\begin{array}{l}2.66 \\
3.00\end{array}$ & $\begin{array}{l}1.00 \text { Agree } \\
0.71 \text { Agree }\end{array}$ \\
\hline $\begin{array}{l}\text { I mentor junior colleagues when they } \\
\text { approach me }\end{array}$ & 3.16 & 0.37 Agree & 3.33 & 0.47 Agree \\
\hline $\begin{array}{l}\text { My mentor simplified my functions } \\
\text { Overall mean }\end{array}$ & $\begin{array}{l}3.30 \\
2.96\end{array}$ & $\begin{array}{r}0.47 \text { Agree } \\
\text { Agree }\end{array}$ & $\begin{array}{l}2.91 \\
2.88\end{array}$ & $\begin{array}{r}0.76 \text { Agree } \\
\text { Agree }\end{array}$ \\
\hline
\end{tabular}

Entries from Table 3 reveal generally high mean scores of respondents' disposition towards mentoring for professional development. It was found that respondents in both institutions have mentors of their choice (UPH $=3.30$; RSUST $=3.08$ ). They can approach any of their senior colleagues for assistance related to academic endeavours $(\mathrm{UPH}=3.08$; RSUST $=3.00)$.

Respondent agreed that they believe in mentoring as a strategy for effective career development $(\mathrm{UPH}=3.25$; RSUST $=4.00)$. They also agreed that mentors can always provide useful guidance and supportive assistance (UPH= 3.30 ; RSUST $=3.16$ ). They equally agreed that they can approach their mentor for other issues other than academic matters (UPH=3.30; RSUST = 2.75).

Results indicate that respondents agreed that they have co-authored with their mentors and they work cooperatively (UPH= 2.60; RSUST $=2.66$ ). Respondents also agreed that their mentors sometimes resort to coaching them $(\mathrm{UPH}=3.30$; RSUST $=3.00)$. Respondents agreed that they can be mentors too if junior colleagues approach them $(\mathrm{UPH}=3.16$; RSUST $=3.33)$. Respondents agreed that their mentors made their functions easier for them (UPH= 3.30; RSUST $=2.91$ ).

\subsection{Teachers' Preferred Domain of Knowledge Management}

The triple mandate of higher education over the ages has revolved around knowledge and its management-research on knowledge creation; teaching/education or knowledge transmission; and society service or 
knowledge dissemination. The emergences of knowledge economy and digital revolution have transformed the demands of the world of works and as such teachers have to learn new approaches to their job in response.

Table 4: Distribution of Lecturers by Agreement that they wish to be mentored (\%)

\begin{tabular}{|c|c|c|c|c|c|c|c|c|}
\hline & \multicolumn{4}{|c|}{ UPH } & \multicolumn{4}{|c|}{ RSUST $(n=60)$} \\
\hline & \multicolumn{2}{|c|}{$\begin{array}{c}\text { M. } \underset{(n=20)}{(\mathrm{M} / \mathrm{A}} \text { A Ed } \\
\text { (n) }\end{array}$} & \multicolumn{2}{|r|}{$\begin{array}{c}\mathrm{PhD} \\
(\mathrm{n}=40)\end{array}$} & \multicolumn{2}{|c|}{$\begin{array}{l}\text { M. Ed/M. A Ed } \\
(n=20)\end{array}$} & \multicolumn{2}{|r|}{$\begin{array}{l}P h D \\
(n=40)\end{array}$} \\
\hline & Agree & Disagree & Agre & Disagree & Agree & Disagree & Agree & e Disagree \\
\hline Research & 100 & - & 88 & 12 & 100 & - & 100 & - \\
\hline Education/Teaching & 75 & 25 & 8 & 62 & 60 & 40 & 95 & 5 \\
\hline Society service & 100 & - & 95 & 5 & 100 & - & 100 & - \\
\hline All domains if needed & 100 & - & 100 & - & 100 & - & 100 & - \\
\hline
\end{tabular}

Table 4 shows that among respondents in UPH, $100 \%$ of the respondents with Masters degree wished to be mentored in the area of research, while $87.5 \%$ of those with $\mathrm{PhD}$ indicated likewise. On the other hand, among respondents in RSUST, all the respondents with Masters degree and $\mathrm{PhD}$ degrees agreed that they wished to be mentored in research endeavour.

Respondents in UPH with Masters degree $(75 \%)$ indicated that they desired mentoring in education/teaching endeavour, while only $37.5 \%$ of $\mathrm{PhD}$ holders indicated so. Among respondents in RSUST however, $60 \%$ of Masters Holders and $95 \%$ of $\mathrm{PhD}$ holders indicated that they desired mentoring in education/teaching endeavour.

It was found that among respondents in UPH $100 \%$ and $95 \%$ of masters and $\mathrm{PhD}$ holders respectively desired mentoring in society service. Among respondents in RSUST, all (100\%) of the respondents with Masters and $\mathrm{PhD}$ degrees respectively indicate desires to be mentored in society service.

The findings of the study revealed that all respondents (100\%) in UPH and RSUST with masters and $\mathrm{PhD}$ degrees respectively desires to be mentored in all the domains of learning as the need arose.

\section{Discussion}

The first training that any employee should receive is induction. This is the institutions' systematic process of helping new employees make sense of and adapt to the work context. The study revealed some shortcomings in the process of inducting new staff into the teaching profession (Table 1).

New entrants into teaching in two faculties of Education were not taken on site tour within and outside the institutions, induction packages were not suitable for adults, the new entrants were not given information packs and 
employees handbooks. Respondents never had institution-wide initial briefing, and they were not taken round the faculties as offices were assigned, neither were they introduced to senior colleagues that might be of help to them later. These shortcomings defeat the aims of induction to the workplace. Inductions are meant to put the new employees at ease; to provide them with basic information about work arrangement, standards of performance and behaviour expected from the new entrants. This revelation affirms the reports of DanLortie (1995) as in Ornstein \& Levina (2006) which claim that teachers learn to teach through trial and error and that new entrants do not have smooth outsideinside transition. The findings also negate the practice of carefully supervised stages that help new entrant learn and adjust to the new job (Robbins \& Coutler, 2005). Those lapses may be attributed to lack of funds. Preparing adequate induction materials are expensive.

Furthermore the study identifies the five common strategies new entrants use for professional development. New entrants share ideas with colleagues; work in partnership with others; take on new responsibilities; attend conferences; and use the internet. To an extent, these findings are in line with the views of Polland, Anderson, Maddock, Swaffield, Warin \& Warwick (2008) on developing within the context of the job, and agree with Vygotsky's social context in learning. However, new entrants do not evaluate data to identify weaknesses; do not attend courses; use peer observation; use CD-ROM; use instructional packages; and audio-based training. These findings might be attributed to lack of funds, lack of awareness, or to the fact that they cannot use other technology-based resources as indicated in Table 2.

The study indicated that new entrants into teaching are disposed towards mentoring. They have mentors of their choices; they can approach any senior colleague for assistance, they believe that mentoring provide good guidance which can sometimes be replaced by coaching. They also accepted the fact that they can be mentors later on. These findings tally with the findings of Lave \& Wenge (1991) that mentees later become mentors. The study confirms the study of Billet (2000) which supports different strategies to keep mentees actively engaged over a period of time. It also supports the works of Young \& Parrewe (2000) which posit that mentors provide social support besides mentoring on work related issues. However, mentors were not assigned to new entrants, for accelerated development (Armstrong, 2009; Menttium, 2004).

On the issue of the domain of knowledge management that new entrants wish to be mentored; the study revealed that all the respondents wished to be mentored virtually in all domains of knowledge management. The triple mandate of Higher Education over the ages has revolved around knowledge and its management- research for knowledge creation; teaching/ education for knowledge transmission; and society service for knowledge dissemination. The fact that new entrants wished to be mentored in these three areas is a major 
concern. This may be attributed to the emergence of knowledge economy and digital revolution. These two events are making teaching profession more challenging. Teachers need to update themselves; they need to be conversant with the use of digital resources for the triple mandate of Higher Education. More specifically, the trend of research in education is on collaborative action research to solve problems at the classroom level (Saddler \& Sadker, 2003; Obanya, 2007). These changes call for professional development for all teachers.

\section{$5 \quad$ Conclusion and Implications for Professional Development}

Inducting new staff into teaching is a very important aspect of training. When new teachers are well inducted into their new jobs and environment, they develop interest and confidence in the job. With the basic information gathered during induction they can fit easily into the job. The study revealed that new entrants into teaching are not well inducted into the job; it identified the strategies new entrants use and those that they do not use for professional development. The study also indicated that new teachers are well disposed towards mentoring as a strategy for professional development; and that they preferred to be mentored in all the domains of knowledge management of research-knowledge creation; teaching/education for knowledge transmission; and society service for knowledge dissemination. These finding are significant because they highlight the needs of new entrants into the teaching profession that should be addressed. Since we are in information-based society, new teachers need to be exposed to technological processes and resources to enable them cope with the demands of knowledge economy.

\section{Recommendations}

Based on the findings the following recommendations were made:

1. Comprehensive formal and informal inductions should be organized for new teachers in higher education institutions. Variety of documents should be issued, and the inductions should not rely on printed words alone. Individuals who are charged with the responsibility should run through the main points. In this way, a more personal touch is provided and queries can be answered.

2. Information and communication technology (ICT) devices, resources and technical assistants should be available for new teachers to enable them 
acquire the necessary technological skill that they can be using for their routine job.

3. New entrants into teaching should be encouraged to use the Internet. They should have access. This will enable them reach out to expert in various fields globally. They will equally have access to other strategies for professional development.

4. Mentors in special fields like in ICT should be assigned to new teachers to enable them learn how to integrate ICT into education. This will enable them appreciate the relationship between ICT, education, and development in a knowledge economy.

5. There should be periodic open interactive sessions for junior and senior lecturers at the faculty level, to establish closer ties for mentoring relationship to develop.

6. New entrants should be availed of opportunities for professional staff exchange programmes where they can go on secondment to update knowledge and share ideas to build capacity.

\section{References}

Armstrong, M. (2009). Armstrong's handbook of human resources management practice. London: Kogan page.

Billet, S. (2000). Guided learning at work. J. workplace learn, 12 (7), 272-285.

Clutterbuck, D. (1998). Learning alliance: Tapping into talents, Institute of Personnel and Development, London.

Dennen, V. P. and Burner, K. J. (2009). The cognitive apprenticeship model in educational practice. Educational Technology 3 (3), 330-336.

Hill, C, W. and McShare, S. L. (2008). Principles of management. Boston: McGraw-Hill.

Hughes, R L., Ginnett, R. C., Curphy, G. J. (2006). Leadership: enhancing the issues of experience. ( $5^{\text {th }}$ Ed.). New York: McGraw-Hill.

Jones, G. R. and George, J. M. (2003). Contemporary management. ( $3^{\text {rd }}$ ed.) New York: McGraw-Hill.

Lave, J. and Wenger, E. (1991). Situated learning: legitimate peripheral participation. New York: Cambridge University Press.

Lee, W. W. and Owens, D. L. (2004). Multimedia -base instructional design. C. A.: Pfeiffer Willey Imprint.

Menttium, Menttium 100 (2004). Cross-contemporary mentoring for high potential women Minneapolis, MN: The Menttium Corporation.

Miller, A. (2002). Mentoring students and young people: A handbook of effective practice. London: Kogan page. 
Obanya P. (2007). Thinking and talking education. Ibadan: Evans Brothers Limited.

Ornstein, A. C. and Levine, D. U. (2006). Foundation of education. ( $9^{\text {th }}$ ed.) Boston: Houghton Mifflin Company.

Polland, A. A., J. Maddock, M. Swaffield, S. Warin and P. Warwick, P. (2008). Reflective Teaching. ( $3^{\text {rd }}$ ed.) New York: Continuous International Publishing Group.

Price, A. (2001). Human resource management in a business context. ( $2^{\text {nd }}$ Ed.) Spain: Thomson.

Sadker, M. P; and Sadker, D. M. (2003). Teachers, Schools and Society. (6 ${ }^{\text {th }}$ Ed.) New York: McGraw-Hill.

Young, A. M. and Perrewe, P. L. (2000). What do you expect? An examination of career-related support and social support among mentors and protégés. J. Manage, 26 (4), 611-632. 
